\title{
KIDNEY INVOLVEMENT IN ADULTS WITH IGA VASCULITIS: EXPERIENCES FROM CLINICAL HOSPITAL DUBRAVA, ZAGREB
}

\author{
IGA-VASKULITIS SA ZAHVAĆANJEM BUBREGA U ODRASLOJ DOBI: \\ ISKUSTVA IZ KLINIČKE BOLNICE DUBRAVA, ZAGREB
}

\author{
Ana Gudelj Gračanin ${ }^{1}$, Tea Mikula ${ }^{2}$, Ivica Horvatić ${ }^{3}$, Luka Torić ${ }^{3}$, Majda Golob ${ }^{1}$, \\ Jasminka Dobša ${ }^{4}$, Matea Liskij ${ }^{2}$, Gabrijela Buljan², Karla Draženović ${ }^{2}$, Matej Nedićs, \\ Danica Galešić Ljubanović ${ }^{6}$, Krešimir Galešić ${ }^{3}$
}

\author{
${ }^{1}$ Division of Clinical Immunology, Allergology and Rheumatology, Department of Internal Medicine, School of Medicine \\ University of Zagreb, Clinical Hospital Dubrava, Zagreb, Croatia / Zavod za kliničku imunologiju, alergologiju i reumatologiju, \\ Klinika za unutarnje bolesti Medicinskog fakulteta Sveučilišta u Zagrebu, Klinička bolnica Dubrava, Zagreb, Hrvatska; \\ ${ }^{2}$ School of Medicine of the University of Zagreb, Zagreb, Croatia / Medicinski fakultet Sveučilišta u Zagrebu, Zagreb, Hrvatska; \\ ${ }^{3}$ Division of Nephrology and Dialysis, Department of Internal Medicine, School of Medicine University of Zagreb, \\ Clinical Hospital Dubrava, Zagreb, Croatia / Zavod za nefrologiju i dijalizu, Klinika za unutarnje bolesti \\ Medicinskog fakulteta Sveučilišta u Zagrebu, Klinička bolnica Dubrava, Zagreb, Hrvatska; \\ ${ }^{4}$ Faculty of Organization and Informatics, University of Zagreb, Varaždin, Croatia \\ / Fakultet organizacije i informatike, Sveučilište u Zagrebu, Varaždin, Hrvatska \\ ${ }^{5}$ Polyclinic Nedić, Slatina, Croatia / Poliklinika Nedić, Slatina, Hrvatska \\ ${ }^{6}$ Department of Pathology, Clinical Hospital Dubrava, Zagreb, Croatia \\ / Zavod za patologiju, Klinička bolnica Dubrava, Zagreb, Hrvatska
}

Corresponding author / Adresa autora za dopisivanje:

Dr. sc. Ana Gudelj Gračanin, dr. med.

Division of Clinical Immunology, Allergology and Rheumatology

/ Zavod za kliničku imunologiju, alergologiju i reumatologiju

Department of Internal Medicine, School of Medicine University of Zagreb

/ Klinika za unutarnje bolesti Medicinskog fakulteta Sveučilišta u Zagrebu

Clinical Hospital Dubrava / Klinička bolnica Dubrava

Av. Gojka Šuška 6, 10040 Zagreb

Croatia / Hrvatska

Fax / faks: +385 12903647

E-mail / e-pošta: agudelj@kbd.hr

Received / Primljeno: May 26, 2020 / 26. svibnja 2020. Accepted / Prihvaćeno: November 19, 2020 / 19. studenoga 2020.

\section{ABSTRACT}

Introduction: IgA vasculitis, formerly named Henoch-Schönlein purpura, is a systemic small-vessel vasculitis that occurs commonly in children, while in adults, the disease remains rare. It is characterised by non-thrombocytopenic palpable purpura, arthritis, arthralgia, kidney disease and gastrointestinal pain. This study aimed to determine clinical signs and symptoms, laboratory and pathohistological parameters and therapy of IgA vasculitis in adults with renal involvement, by conducting our research on a sample of patients of a tertiary referral hospital.

Research subjects and methods: In this retrospective cohort study, patients treated at Clinical Hospital Dubrava from 2011 to 2019 were included, who were diagnosed with IgA vasculitis, based on clinical, laboratory and pathohistological criteria. Clinical and laboratory parameters, were determined through the use of methods commonly used in clinical practice. In patients with symptoms and signs of kidney involvement and after patients' consent, kidney biopsy was performed, and analysed by light, immunofluorescence and electron microscopy.

Results: twenty-two adults (12 M, $10 \mathrm{~F}$ ), whose median age was 57, were included in our study. Palpable purpura and nephritis were present in all patients. Thirteen (59.1\%) patients had arthralgia and five of them (22.5\%) experienced abdominal pain. Respiratory infection preceded vasculitis in six $(27.3 \%)$ patients, six patients $((27.3 \%)$ were taking medications and got vaccinated prior to the occurrence of vasculitis, and in ten (45.4\%) patients the predisposing factor was unknown. Asymptomatic hematuria was present in ten $(47.6 \%)$, subnephrotic proteinuria in three (14.3\%), nephrotic syndrome in nine (42.9\%) and nephritic syndrome in three (14.3\%) patients. According to the findings of kidney biopsy, which was performed on 18 patients, eleven $(61.6 \%)$ had mesangial proliferation, fourteen 
(77.8\%) had endocapillary proliferation, and eleven (61.6\%) had extracapillary (crescents) proliferation. After the diagnosis, renin-angiotensin inhibitors were used by eighteen (81.8\%) patients, glucocorticoids by twenty-one (95.5\%) and cyclophosphamide by five (22.7\%) patients. Patient follow-up was performed for 23 to 84 months and, in the said period, all of them had improved or stagnant renal function, except for one patient who died.

Conclusion: Renal manifestations of IgA vasculitis may change the commonly mild course of this disease and lead to an increase in morbidity as well as affect the type and duration of treatment. So, in everyday work, it is important to determine characteristics of renal changes in IgA vasculitis in order for an adequate therapeutic option to be applied.

Key wORDs: Purpura, Schoenlein-Henoch - complications, diagnosis, drug therapy; Kidney diseases - diagnosis, drug therapy, etiology; Kidney - pathology; Biopsy; Glomerulonephritis, IgA - dijagnoza, farmakoterapija, patologija; Immunoglobulin A; Arthralgia - etiology; Abdominal pain - etiology; Glucocorticoids - therapeutic use; Angiotensin - converting enzyme inhibitors - therapeutic use; Angiotensin receptor antagonists - therapeutic use

\section{SAŽETAK}

Uvod: IgA-vaskulitis, prije nazivan Henoch-Schönleinova purpura, vaskulitis je malih krvnih žila posredovan imunoglobulinom A (IgA). Najčešće obolijevaju djeca, dok je u odraslih incidencija manja. Kliničkom slikom dominiraju palpabilna, netrombocitopenična purpura, artralgije, artritis, znakovi bubrežne bolesti i abdominalna bol. Cilj ovog istraživanja bio je utvrđivanje kliničkih i laboratorijskih karakteristika te načina liječenja odraslih oboljelih od IgA-vaskulitisa sa zahvaćanjem bubrega na uzorku bolesnika iz jednoga tercijarnog centra.

Ispitanici i metode: U retrospektivno kohortno istraživanje uključeni su bolesnici liječeni u razdoblju od 2011. do 2019. godine u Kliničkoj bolnici Dubrava u Zagrebu, kojima je na osnovi kliničkih, laboratorijskih i patohistoloških kriterija dijagnosticiran IgA-vaskulitis. Klinički i laboratorijski parametri određivani su metodama uobičajenima u kliničkoj praksi. U bolesnika sa znakovima zahvaćanja bubrega učinjene su biopsija bubrega i analiza svjetlosnom, imunofluorescentnom i elektronskom mikroskopijom.

Rezultati: U istraživanju su sudjelovala ukupno 22 bolesnika (12 muškaraca, 10 žena), medijana dobi 57 godina. Svi su bolesnici imali purpuru i znakove bubrežne bolesti. Artralgije je imalo 13 -ero $(59,1 \%)$ bolesnika, a bol u trbuhu njih 5-ero (22,5\%). Infekcija dišnog sustava prethodila je vaskulitisu u 6-ero $(27,3 \%)$ bolesnika, lijekovi i cjepiva također u njih 6-ero (27,3\%), a u 10-ero (45,4\%) bolesnika predisponirajući čimbenik bio je nepoznat. Asimptomatsku hematuriju imalo je 10-ero (47,6\%) bolesnika, subnefrotsku proteinuriju njih troje (14,3\%), nefrotski sindrom 9-ero $(42,9 \%)$, a nefritički sindrom imalo je također troje (14,3\%) bolesnika. Prema nalazu biopsije bubrega, koja je učinjena u 18-ero bolesnika, mezangijsku proliferaciju imalo je njih 11-ero $(61,1 \%)$, endokapilarnu proliferaciju 14-ero $(77,8 \%)$, a ekstrakapilarnu proliferaciju (polumjesece) imalo je 11-ero (61,1\%) bolesnika. Nakon postavljanja dijagnoze terapiju inhibitorima sustava renin-angiotenzin primalo je 18-ero (81,8\%) bolesnika, 21 bolesnik $(95,5 \%)$ dobivao je glukokortikoide, a njih 5-ero (22,7\%) liječeno je ciklofosfamidom. Bolesnici su praćeni tijekom razdoblja od 23 do 84 mjeseca, a u svih se, osim u jedne bolesnice, bubrežna funkcija poboljšala ili je stagnirala.

Zaključak: Bubrežne manifestacije IgA-vaskulitisa mijenjaju inače blagi tijek bolesti, dovode do porasta morbiditeta i utječu na trajanje liječenja. Pri svakodnevnom radu valja utvrditi značajke bubrežnih promjena kod IgA-vaskulitisa da bismo na temelju tih obilježja primijenili prikladnu terapiju.

KLJUČNE RIJEČI: Henoch-Schönleinova purpura - dijagnoza, farmakoterapija, komplikacije; Bubrežne bolesti dijagnoza, etiologija, farmakoterapija; Bubreg - patologija; IgA nefropatija - dijagnoza, farmakoterapija, patologija; Imunoglobulin A; Biopsija; Artralgija - etiologija; Abdominalna bol - etiologija; Glukokortikoidi - terapijska uporaba; Inhibitori angiotenzin konvertirajućeg enzima - terapijska uporaba; Antagonisti receptora angiotenzina - terapijska uporaba

\section{INTRODUCTION}

According to the classification proposed in 1994 at the International Chapel Hill Consensus Conference on the Nomenclature of Systemic Vasculitides, immunoglobulin A-mediated vasculitis (IgA vasculitis) is a systemic, nongranulomatous small-vessel (arterioles, venules and capillaries) vasculitis. Systemic vasculitis is most common in children, with an annual incidence of 10 to 30 per 100,000 (1). It occurs significantly less frequently in adults, with an incidence of 0.8 to 1.8 per

\section{UVOD}

Prema klasifikaciji iz Chapel Hilla, vaskulitis posredovan imunoglobulinom A (IgA-vaskulitis) sustavni je negranulomatozni vaskulitis malih krvnih žila (arteriola, venula i kapilara). Najčešći je sustavni vaskulitis $\mathrm{u}$ djece $\mathrm{s}$ godišnjom incidencijom od 10 do 30 na 100.000 (1). Znatno rjeđe pojavljuje se u odraslih uz incidenciju od 0,8 do 1,8 na 100.000 (2). Histopatološki, riječ je o leukocitoklastičkom vaskulitisu s neutrofilnom infiltracijom stijenka zahvaćenih krvnih žila 
100,000 (2). From a histopathological standpoint, this is a leukocytoclastic vasculitis with neutrophilic infiltration of the walls of the affected blood vessels and IgA immunocomplex deposits, with possible development of necrosis $(3,4)$. Disease etiology is not known. It is most likely an interaction of genetic and external factors, which triggers the formation of antigen-antibody immune complexes, with the development of immune-mediated inflammation of the wall of small blood vessels (5). Patients carrying certain HLA antigens are more likely to develop IgA vasculitis: HLADRB1:01, HLA-B41:02 and HLA-B35 $(6,7)$. The most common external factors associated with the occurrence of the disease in children are the causes of upper and lower respiratory tract infections such as streptococci, staphylococci, and parainfluenza viruses (8). IgA vasculitis in children can also occur after acute gastroenteritis, urinary tract infections and vaccinations. In adults, it is most commonly associated with the administration of drugs and vaccines, toxins, food allergens, neoplasms, and insect bites (9). Most patients with IgA vasculitis have high serum IgA levels. IgA vasculitis is manifested by a tetrad of symptoms: nonthrombocytopenic purpura, arthritis or arthralgia, kidney involvement, and abdominal pain. According to the current 2008 EULAR/PRINTO/PRES classification criteria from Ankara, the basic criterion is palpable purpura in patients without thrombocytopenia and coagulopathy with at least one of four other symptoms (10). Skin changes initially manifest as erythema, urticaria, and maculopapular rash, then progress to ecchymoses and petechiae. They are most often distributed on the extensor of the lower and upper extremities (11). According to a study conducted by Kang et al, the incidence of purpura in the upper extremities was higher in adults than in children (9). In about a quarter of patients, IgA vasculitis begins with arthralgia and/or arthritis, and this occurs significantly more often in children than in adults $(9,12)$. It is most commonly a case of oligoarthritis involving the knee, hip, and ankle (13). Approximately two-thirds of patients, predominantly children, experience abdominal pain caused by submucosal hemorrhage and small bowel wall thickening as part of their clinical features of IgA vasculitis $(4,14)$. Kidney involvement occurs in more than a third of all patients, usually within the period of one month after the onset of systemic symptoms (15). According to the EULAR/PRINTO/PRES criteria for IgA vasculitis, kidney disease is characterised by proteinuria, hematuria, or histopathological nephritis with IgA deposits in the mesangium (10). Risk factors for the development of nephritis are older age, disease complications, male sex, duration of purpura, relapse of the disease, leukocytosis, thrombocytosis, and low complement 3 (C3) values (16). Kidney disease is sig- i depozitima imunokompleksa IgA, uz mogući razvoj nekroza $(3,4)$. Etiologija bolesti nije poznata. Najvjerojatnije se radi o interakciji genskih i vanjskih čimbenika, što pokreće stvaranje imunosnih kompleksa antigen - protutijelo, uz razvoj imunosno posredovane upale stijenke malih krvnih žila (5). Veću vjerojatnost za razvoj IgA-vaskulitisa pokazuju bolesnici nositelji određenih antigena HLA: HLA-DRB1 01, HLA-B41:02 i HLA-B35 $(6,7)$. Najčešći vanjski čimbenici koji se povezuju s nastankom bolesti u djece jesu uzročnici infekcija gornjeg i donjega dišnog sustava kao što su streptokoki, stafilokoki te virus parainfluence (8). IgA-vaskulitis u djece može nastati i poslije akutnih gastroenteritisa, infekcija mokraćnog sustava i cijepljenja. U odraslih se najčešće povezuje s primjenom lijekova i cjepiva, toksinima, alergenima iz hrane, neoplazmama i ubodima kukaca (9). Većina bolesnika $s$ IgA-vaskulitisom ima povišenu serumsku razinu IgA. IgA-vaskulitis očituje se tetradom simptoma: netrombocitopeničnom purpurom, artritisom ili artralgijama, zahvaćanjem bubrega i bolima u trbuhu. Prema aktualnim klasifikacijskim kriterijima EULAR/PRINTO/ PRES-a iz Ankare od 2008. godine, osnovni kriterij jest palpabilna purpura bez trombocitopenije i koagulopatije uz barem još jedan od četiriju simptoma (10). Kožne se promjene u početku očituju kao eritem, urtike i makulopapulozni osip, a zatim prelaze u ekhimoze i petehije. Najčešće su raspoređene po ekstenzornim stranama donjih i gornjih ekstremiteta (11). U istraživanju Kanga i suradnika uočena je veća pojavnost purpure u području gornjih ekstremiteta u odraslih u usporedbi s djecom (9). U oko četvrtine bolesnika IgA-vaskulitis započinje artralgijama $\mathrm{i} / \mathrm{ili}$ artritisom, $\mathrm{i}$ to znatno češće u djece nego u odraslih $(9,12)$. Najčešće je riječ o oligoartritisu sa zahvaćanjem koljena, kuka i gležnja (13). Približno dvije trećine bolesnika, pretežno djece, u sklopu kliničke slike IgA-vaskulitisa ima bol u trbuhu uzrokovanu submukoznim krvarenjem i edemom stijenke tankog crijeva $(4,14)$. Zahvaćanje bubrega javlja se u više od trećine bolesnika, obično do mjesec dana poslije nastupa sustavnih simptoma (15). Prema kriterijima EULAR/PRINTO/PRES-a za IgA-vaskulitise, bubrežnu bolest karakteriziraju proteinurija, hematurija ili histopatološki nefritis s depozitima IgA u mezangiju (10). Rizični čimbenici za razvoj nefritisa jesu viša dob, komplikacije bolesti, muški spol, trajanje purpure, relaps bolesti, leukocitoza, trombocitoza i niske vrijednosti komplementa 3 (C3) (16). Bolest bubrega znatno se češće pojavljuje u starije djece i odraslih uz težu kliničku sliku (9). Dijagnoza IgA-nefritisa temelji se na kliničkoj prezentaciji, a potvrđuje dokazom depozita IgA u bioptatu bubrega. Biopsija bubrega s patohistološkom dijagnozom indicirana je kod nejasnog i težega bubrežnog oštećenja. U patohistološkoj dijagnostici bolesnika s IgA-nefritisom upo- 
nificantly more common in older children and adults with more severe clinical features (9). The diagnosis of IgA nephropathy is based on clinical presentation and is confirmed by the evidence of IgA deposition in the kidney biopsy. Kidney biopsy with pathohistological diagnosis is indicated for obscure and severe renal impairment. Several classifications are used in the pathohistological diagnosis of patients with IgA nephropathy: the ISKDC classification (International Study of Kidney Disease in Children), the Haas system of classification and the Oxford classification $(17-20)$. Individual morphological features such as mesangial hypercellularity, endocapillary proliferation, segmental glomerulosclerosis, and tubular atrophy / interstitial fibrosis are assessed by the Oxford classification. In extremely rare cases, IgA vasculitis can manifest as central nervous system (CNS) vasculitis, encephalopathy, ischemic stroke, and pulmonary affection $(21,22)$. It is most often a case of self-limiting disease with a good prognosis. Regular monitoring and treatment are required in patients with occurring symptoms of kidney involvement, as well as gastrointestinal tract, respiratory system or CNS involvement. Public recommendations and unanimous views of umbrella organisations are still lacking in the treatment of this disease. Depending on the clinical features, symptomatic treatment, glucocorticoids, and in the most severe cases, immunosuppressants such as mycophenolate mofetil, azathioprine, cyclophosphamide, and rituximab are used.

\section{RESEARCH SUBJECTS AND METHODS}

This cohort study was conducted on patients over 18 years of age, who were treated at the Division of Clinical Immunology, Allergology and Rheumatology and at the Division of Nephrology and Dialysis of the Clinical Hospital Dubrava in Zagreb. The study included patients who were treated at the aforementioned divisions in the period from 2011 to 2019. The diagnosis of IgA vasculitis was made on the basis of patient's medical history, clinical status, common laboratory and imaging methods in clinical practice, skin biopsy and kidney biopsy. At the first hospitalisation of patients who had an indication (hematuria and proteinuria and azotemia) and who have signed an informed consent, a kidney biopsy was performed under local anesthesia and ultrasound control, by using an automatic biopsy device Biopty (C. R. Bard, USA). Signs of kidney disease were newly occurring hematuria and/or proteinuria and/or a reduction in the estimated glomerular filtration rate (eGFR). Patients with proteinuria were classified into the group suffering from nephrotic syndrome (24-hour urine protein test $>3.5 \mathrm{~g} / 1.73 \mathrm{~m}^{2}$, hypoalbuminemia, hyperlipidemia, oedema) and sub- trebljava se nekoliko klasifikacija: ISKDC-ova (engl. International Study of Kidney Disease in Children), Haasova i Oksfordska klasifikacija (17 - 20). Pojedinačna morfološka obilježja kao što su hipercelularnost mezangija, endokapilarna proliferacija, segmentalna glomeruloskleroza i tubularna atrofija / intersticijska fibroza ocjenjuju se Oksfordskom klasifikacijom. Vrlo se rijetko IgA-vaskulitis može očitovati vaskulitisom središnjega živčanog sustava (SŽS), encefalopatijom, ishemijskim infarktom mozga i afekcijom pluća (21, 22). Najčešće je to samolimitirajuća bolest dobre prognoze. Redovito praćenje i liječenje iziskuju bolesnici s prisutnim simptomima zahvaćenosti bubrega, gastrointestinalnog trakta, respiratornog sustava ili SŽS-a. U liječenju još nedostaju javne preporuke i jednoglasna stajališta krovnih društava. Ovisno o kliničkoj slici, primjenjuju se simptomatsko liječenje, glukokortikoidi, a u najtežim slučajevima i imunosupresivi kao što su mikofenolat-mofetil, azatioprin, ciklofosfamid i rituksimab.

\section{ISPITANICI I METODE}

Ovo kohortno istraživanje provedeno je među bolesnicima starijima od 18 godina u Zavodu za kliničku imunologiju, alergologiju i reumatologiju i u Zavodu za nefrologiju i dijalizu Kliničke bolnice Dubrava u Zagrebu. U njega su bili uključeni bolesnici koji su u tim zavodima liječeni od 2011. do 2019. godine. Dijagnoza IgA-vaskulitisa postavljena je na osnovi anamneze, kliničkog statusa, uobičajenih laboratorijskih i slikovnih metoda u kliničkoj praksi, biopsije kože te biopsije bubrega. Pri prvoj hospitalizaciji bolesnicima koji su imali indikaciju (hematurija i proteinurija te azotemija) i potpisali pristanak informiranog pacijenta učinjena je biopsija bubrega u lokalnoj anesteziji pod kontrolom ultrazvuka, i to s pomoću automatskog uređaja za biopsiju Biopty (C. R. Bard, SAD). Znakovi bubrežne bolesti bili su novonastala hematurija i/ili proteinurija i/ili smanjenje procijenjene glomerularne filtracije (eGFR). Bolesnici s proteinurijom klasificirani su u nefrotski sindrom (24-satna proteinurija $>3,5$ $\mathrm{g} / 1,73 \mathrm{~m}^{2}$, hipoalbuminemija, hiperlipidemija, edemi) i subnefrotsku proteinuriju $\left(<3,5 \mathrm{~g} / 1,73 \mathrm{~m}^{2}\right)$. Nefritički sindrom definiran je nalazom hematurije i novonastalog smanjenja eGFR-a i klasificiran kao akutan (smanjenje eGFR-a nastalo u nekoliko dana) ili brzoprogresivan (smanjenje eGFR-a nastalo tijekom nekoliko tjedana). Nalaz hematurije bez proteinurije i smanjenog eGFR-a klasificiran je kao asimptomatska hematurija. Bubrežno tkivo analizirano je svjetlosnim mikroskopom nakon bojenja hemalaun-eozinom, PAS-om, Massonovim trikromnim bojenjem i Jonesovim bojenjem, imunofluorescentnim mikroskopom nakon bojenja protutijelima za IgG, IgA, IgM, C3, C1q, fibrinogen, albumin, $\kappa$ i $\lambda$-lance imunoglobulina te elektron- 
nephrotic proteinuria $\left(<3.5 \mathrm{~g} / 1.73 \mathrm{~m}^{2}\right)$. Nephritic syndrome was defined by the finding of hematuria and the newly occurring reduction in the eGFR and was classified as acute (reduction in the eGFR occurring within a few days) or rapidly progressive (reduction in the eGFR occurring over several weeks). The finding of hematuria without proteinuria and reduced eGFR was classified as asymptomatic hematuria. Renal tissue was analysed by light microscopy after staining with hematoxylin and eosin, Periodic acid-Schiff (PAS) staining, Masson's trichrome stain and Jones' stain, immunofluorescence microscope after immunostaining with antibodies for IgG, IgA, IgM, C3, C1q, fibrinogen, albumin, kappa $(\kappa)$ and lambda $(\lambda)$ immunoglobulin light chains and electron microscopy. Some parameters of the Oxford classification and other parameters were used in the pathohistological diagnosis. The pathohistological parameters analysed were the following: degree of interstitial fibrosis and tubular atrophy (IF/TA, expressed in \%), semiquantitative determination of the degree of hyalinosis of the arterioles and changes in the arteries (fibrointimal thickening of the arterial walls) (0 - absence; 1 - mild; 2 - moderate; 3 - severe), degree of deposition of immunoglobulins IgA, IgM, IgG, complement components $\mathrm{C} 3$ and $\mathrm{Clq}$ ( 0 - absence; 1 mild; 2 - moderate; 3 - severe), percentage of glomeruli with focal segmental glomerulosclerosis and completely connectively altered glomeruli. The occurrences of mesangial proliferation, endocapillary proliferation, extracapillary proliferation and the occurrence of podocyte foot fusion were analysed as well. Patients were monitored once a month for the first 6 months and following that period, every 3 months for the next 6 months and consequently every 6 months. Serum creatinine, eGFR, and 24-hour urine protein tests were monitored at each follow-up. Follow-up outcomes were patient survival, development of end-stage chronic kidney disease (defined by permanently reduced eGFR $<15 \mathrm{~mL} / \mathrm{min} / 1.73 \mathrm{~m}^{2}$ or the need for permanent renal replacement therapy or kidney transplantation) and a permanent $50 \%$ reduction in the eGFR.

In statistical data processing, variables were presented as median and interquartile (IQ) range, and categorical variables were presented by number and percentage. The analysis was performed using computer programmes SPSS Statistics 19.0 for Windows (SPSS Inc., Chicago, IL, USA) and MedCalc 11.4.2.0.

\section{RESULTS}

Demographic and clinical characteristics of patients are shown in Table 1. Parameters of renal function are shown in Table 2. Laboratory parameters of patients with IgA vasculitis are shown in Table 3. Kidney biopsy was performed on 18 patients, and in case of the remaining 4 patients, who exhibited symptoms of as- skim mikroskopom. Pri patohistološkoj dijagnostici upotrijebljeni su pojedini parametri Oksfordske klasifikacije i drugi parametri. Analizirani patohistološki parametri bili su: stupanj intersticijske fibroze i tubularne atrofije (IFTA, izražen u \%), semikvantitativno određivanje stupnja hijalinoze arteriola i promjene arterija (fibrointimalno zadebljanje stijenka) (0 - izostanak; 1 - blaga; 2 - umjerena; 3 - jaka), stupnja odlaganja imunoglobulina IgA, IgM, IgG, komponenata komplementa C3 i C1q (0 - izostanak; 1 - blago; 2 umjereno; 3 - jako), postotak glomerula s fokalnom segmentalnom glomerulosklerozom i potpuno vezivno promijenjenih glomerula. Također, analizirano je postojanje mezangijske proliferacije, endokapilarne proliferacije, ekstrakapilarne proliferacije i postojanje fuzije nožica podocita. Bolesnici su praćeni jedanput na mjesec prvih 6 mjeseci pa svaka 3 mjeseca sljedećih 6 mjeseci, a zatim svakih 6 mjeseci. Na svakoj kontroli praćeni su serumska koncentracija kreatinina, eGFR i 24-satna proteinurija. Praćeni ishodi bili su preživljenje bolesnika, razvoj završnog stadija kronične bubrežne bolesti (definiran trajno smanjenim eGFR-om $<15$ $\mathrm{mL} / \mathrm{min} / 1,73 \mathrm{~m}^{2}$ ili potrebom za trajnim nadomještanjem bubrežne funkcije ili transplantacijom bubrega) i trajno 50\%-tno smanjenje eGFR-a.

U statističkoj obradi podataka varijable su prikazane kao medijan i interkvartilni (engl. interquartile - IQ) raspon, a kategorijske varijable prikazane su brojem i postotkom. Analiza je provedena s pomoću računalnih programa SPSS 19.0 for Windows (SPSS Inc., Chicago, IL, SAD) i MedCalc 11.4.2.0.

\section{REZULTATI}

Demografske i kliničke karakteristike bolesnika prikazane su na tablici 1. Parametri bubrežne funkcije prikazani su na tablici 2. Na tablici 3. prikazani su laboratorijski parametri oboljelih od IgA-vaskulitisa. Biopsija bubrega učinjena je u 18-ero bolesnika, a u preostala 4 bolesnika, koji su se prezentirali asimptomatskom hematurijom, nije izvedena zbog blagog tijeka bolesti i jer bolesnici na nju nisu pristali. Nalazi bubrežne biopsije prikazani su na tablici 4. Lijekovi koji su primjenjivani u liječenju prikazani su na tablici 5 . Bolesnici su praćeni tijekom razdoblja od 23 do 84 mjeseca te im se bubrežna funkcija poboljšala ili je stagnirala, osim u jedne bolesnice liječene hemodijalizom, a koja je zbog brojnih komorbiditeta i visoke dobi preminula.

\section{RASPRAVA}

U ovom istraživanju analizirali smo kliničke i laboratorijske karakteristike, način liječenja $\mathrm{i}$ ishode $\mathrm{u}$ odraslih bolesnika oboljelih od IgA-vaskulitisa sa zahvaćanjem bubrega, koje su dijagnosticirali i liječili imunolog-reumatolog i nefrolog tijekom 8-godišnjeg 
TABLE 1. Demographic and clinical characteristics of patients with $\operatorname{IgA}$ vasculitis

TABLICA 1. Demografske i kliničke karakteristike oboljelih od IgA-vaskulitisa

\begin{tabular}{|c|c|c|}
\hline & $\begin{array}{c}\text { All patients } \\
\text { / Svi bolesnici }(\mathrm{n}=22)\end{array}$ \\
\hline \multicolumn{2}{|c|}{$\begin{array}{l}\text { Age during diagnosis (in years) } \\
\text { / Dob pri dijagnozi (godine) }\end{array}$} & $57(40-71)$ \\
\hline \multicolumn{2}{|c|}{ Sex (F/M) / Spol (Ž/M) } & $10(45,5 \%) / 12(55,5 \%)$ \\
\hline \multirow{4}{*}{$\begin{array}{l}\text { Organ system } \\
\text { involved } \\
\text { / zahvaćeni } \\
\text { organski sustav }\end{array}$} & Joints / Zglobovi & $13(59,1 \%)$ \\
\hline & $\begin{array}{l}\text { Digestive system } \\
\text { / Abdominalni } \\
\text { sustav }\end{array}$ & $5(22,7 \%)$ \\
\hline & $\begin{array}{l}\text { Nervous system } \\
\text { / Živčani sustav }\end{array}$ & $0(0 \%)$ \\
\hline & Renal / Bubreg & $21(95,5 \%)$ \\
\hline \multirow{5}{*}{$\begin{array}{l}\text { Predisposing } \\
\text { factor } \\
\text { / Predisponirajući } \\
\text { čimbenik }\end{array}$} & $\begin{array}{l}\text { Unknown } \\
\text { / Nepoznat }\end{array}$ & $9(40,9 \%)$ \\
\hline & $\begin{array}{l}\text { Respiratory } \\
\text { infection } \\
\text { / Respiratorna } \\
\text { infekcija }\end{array}$ & $6(27,3 \%)$ \\
\hline & $\begin{array}{l}\text { Medications/ } \\
\text { vaccines } \\
\text { / Lijekovi/cjepiva }\end{array}$ & $6(27,3 \%)$ \\
\hline & $\begin{array}{l}\text { Neoplasms } \\
\text { / Neoplazme }\end{array}$ & $0(0 \%)$ \\
\hline & Other / Ostalo & $1(4,5 \%)$ \\
\hline
\end{tabular}

$F / \check{Z}=$ females / žene; $M=$ muškarci / males

ymptomatic hematuria, it was not performed due to the mild course of the disease and because the patients did not consent to it. Parameters of kidney biopsy are shown in Table 4. Medications used in the treatment are shown in Table 5. Patient follow-up was performed for 23 to 84 months and, in the said period, all of them had improved or stagnant renal function, except for one patient treated with hemodialysis, who died due to numerous comorbidities and old age.

\section{DISCUSSION}

In this study, we analysed the clinical and laboratory characteristics, treatment methods, and outcomes in adult patients with renal involvement with IgA vasculitis, who were diagnosed and treated by an immunologist-rheumatologist and nephrologist over an 8-year period. IgA vasculitis is a disease that primarily occurs in children and is rare in adults $(2,23)$. In clinical practice, there is a lack of data on the characteristics of the disease and recommendations on diagnostic procedures and treatment of IgA vasculitis with kidney involvement in adulthood. In contrast to IgA vasculitis in children, when the disease is most often preceded by infections of the respiratory system, the use of medications and neoplasms is more often mentioned in adults
TABLE 2. Parameters of renal function in patients with IgA vasculitis

TABLICA 2. Parametri bubrežne funkcije oboljelih od IgA-vaskulitisa

\begin{tabular}{|c|c|c|}
\hline & & $\begin{array}{c}\text { All patients } \\
\text { / Svi bolesnici }(\mathrm{n}=22)\end{array}$ \\
\hline \multicolumn{2}{|l|}{$\begin{array}{l}\text { Serum creatinine } \\
\text { / S-kreatinin }(\mu \mathrm{mol} / \mathrm{L})\end{array}$} & $93,0(78,0-139,0)$ \\
\hline \multicolumn{2}{|c|}{$\begin{array}{l}\text { eGFR }\left(\mathrm{ml} / \mathrm{min} / 1.73 \mathrm{~m}^{2}\right) \\
\text { (according to the CKD-EPI equation) } \\
\text { / eGFR }(\mathrm{mL} / \mathrm{min} / 1,73 \mathrm{~m} 2) \\
\text { (prema formuli CKD-EPI) }\end{array}$} & $59,36(41,10-93,88)$ \\
\hline \multicolumn{2}{|c|}{$\begin{array}{l}\text { 24-hour urine protein test } \\
\text { / 24-satna proteinurija }(\mathrm{g} / \mathrm{dU})\end{array}$} & $1,87(0,44-5,58)$ \\
\hline \multicolumn{2}{|c|}{$\begin{array}{l}\text { Hematuria (sediment) } \\
\text { / Hematurija (sediment) }\end{array}$} & $22(7-50)$ \\
\hline \multicolumn{2}{|c|}{$\begin{array}{l}\text { Asymptomatic hematuria } \\
\text { / Asimptomatska hematurija }\end{array}$} & $10(47,6 \%)$ \\
\hline \multicolumn{2}{|c|}{$\begin{array}{l}\text { Subnephrotic proteinuria } \\
\text { / Subnefrotska proteinurija }\end{array}$} & $3(14,3 \%)$ \\
\hline \multicolumn{2}{|l|}{$\begin{array}{l}\text { Nephrotic syndrome } \\
\text { / Nefrotski sindrom }\end{array}$} & $9(42,9 \%)$ \\
\hline \multirow{2}{*}{$\begin{array}{l}\text { Nephritic syndrome } \\
\text { / Nefritički sindrom }\end{array}$} & $\begin{array}{l}\text { acute } \\
\text { / akutan }\end{array}$ & $2(9,5 \%)$ \\
\hline & \begin{tabular}{|l|} 
rapidly \\
progressive \\
/ brzoprogresivan
\end{tabular} & $1(4,8 \%)$ \\
\hline
\end{tabular}

$S=$ serum; $e G F R=$ estimated glomerular filtration rate

/ procijenjena glomerularna filtracija

TABLE 3. Laboratory parameters of patients with IgA vasculitis TABLICA 3. Laboratorijski parametri oboljelih od IgA-vaskulitisa

\begin{tabular}{|l|c|}
\hline & $\begin{array}{c}\text { All patients } \\
\text { / Svi bolesnici (n =22) }\end{array}$ \\
\hline Hemoglobin (g/L) & $129(115-135)$ \\
\hline RDW (\%) & $13,7(13,2-14,2)$ \\
\hline Serum albumin / S-albumin (g/L) & $133(31-40)$ \\
\hline Serum complement C3 / S-C3 (g/L) & $19(86,4 \%) / 3(13,6 \%)$ \\
\hline $\begin{array}{l}\text { Serum complement category C3 } \\
\text { (normal/elevated) / Kategorija S-C3 } \\
\text { (normalan/povišen) }\end{array}$ & $0,33(0,23-0,40)$ \\
\hline Serum complement C4 / S-C4 (g/L) & $17(77,3 \%) / 5(22,7 \%)$ \\
\hline $\begin{array}{l}\text { Serum complement category C4 } \\
\text { (normal/elevated) / Kategorija S-C4 } \\
\text { (normalan/povišen) }\end{array}$ & $4,18(2,72-5,34)$ \\
\hline Serum IgA / S-IgA (g/L)
\end{tabular}

$R D W=$ Red blood cell Distribution Width / širina distribucije eritrocita; $S=$ serum

razdoblja. IgA-vaskulitis bolest je koja se ponajprije javlja u djece, a u odraslih je rijetka $(2,23)$. U kliničkoj praksi nedostaju podatci o karakteristikama bolesti i preporuke o dijagnostičkim postupcima i načinu liječenja IgA-vaskulitisa sa zahvaćanjem bubrega u odra- 
TABLE 4. Pathohistological features of renal biopsies (in patients who underwent renal biopsy)

TABLICA 4. Patohistološka obilježja bioptata bubrega (u bolesnika kojima je izvedena biopsija bubrega)

\begin{tabular}{|c|c|}
\hline & All patients / Svi bolesnici $(\mathrm{n}=18)$ \\
\hline Glomeruli number in a kidney biopsy / Broj glomerula u bioptatu & $20(15-28)$ \\
\hline Glomeruli number with FSGS (\%) / Broj glomerula s FSGS-om (\%) & $0(0-0)$ \\
\hline $\begin{array}{l}\text { Number of completely altered glomeruli in the glomerular capillary network (\%) } \\
\text { / Broj potpuno vezivno promijenjenih glomerula (\%) }\end{array}$ & $8,01(2,78-15,0)$ \\
\hline Patients with mesangial proliferation / Pacijenti s mezangijskom proliferacijom & $11(61,1 \%)$ \\
\hline Patients with endocapillary proliferation / Pacijenti s endokapilarnom proliferacijom & $14(77,8 \%)$ \\
\hline $\begin{array}{l}\text { Patients with extracapillary proliferation (crescents) }<25 \% \text { glomeruli / } \geq 5 \% \text { glomeruli) } \\
\text { / Pacijenti s ekstrakapilarnom proliferacijom (polumjesecima) } \\
(<25 \% \text { glomerula / } \geq 5 \% \text { glomerula) }\end{array}$ & $8(44,4 \%) / 3(16,7 \%)$ \\
\hline IFTA $(\%)$ & $2,5(0-10,0)$ \\
\hline MEST T-score $(0$ / 1) / MEST T-zbroj $(0 / 1)$ & $16(88,9 \%) / 2(11,1 \%)$ \\
\hline Arteriolar hyalinosis $(0$ / 1 / 2 / 3) / Arteriolarna hijalinoza $(0$ / 1 / 2 / 3) & $7(38,9 \%) / 6(33,3 \%) / 1(5,6 \%) / 4(22,2 \%)$ \\
\hline $\begin{array}{l}\text { Fibrointimal thickening of the arterial walls }(0 / 1 / 2 / 3) \\
\text { / Fibrointimalno zadebljanje arterija }(0 / 1 / 2 / 3)\end{array}$ & $11(61,1 \%) / 3(16,7 \%) / 4(22,2 \%) / 0(0 \%)$ \\
\hline IgA by IF microscopy (1 / 2 / 3) / IgA na IF mikroskopiji (1 / 2 / 3) & $5(27,8 \%) / 6(33,3 \%) / 7(38,9 \%)$ \\
\hline IgG by IF microscopy $(0$ / 1 / 2) / IgG na IF mikroskopiji $(0 / 1$ / 2) & $13(72,2 \%) / 4(22,2 \%) / 1(5,6 \%)$ \\
\hline IgM by IF microscopy (0 / 1) / IgM na IF mikroskopiji (0 / 1) & $16(88,9 \%) / 2(11,1 \%)$ \\
\hline C3 by IF microscopy (0 / 1 / 2 / 3) / C3 na IF mikroskopiji (0 / 1 / 2 / 3) & $7(38,9 \%) / 9(50,0 \%) / 1(5,6 \%) / 1(5,6 \%)$ \\
\hline C4 and C1q by IF microscopy / C4 i C1q na IF mikroskopiji & Svi negativni \\
\hline $\begin{array}{l}\text { Podocyte foot fusion (non-existent/ focal/diffuse) } \\
\text { / Fuzija nožica podocita (ne / fokalna / difuzna) }\end{array}$ & $11(61,1 \%) / 6(33,3 \%) / 1(5,6 \%)$ \\
\hline
\end{tabular}

FSGS = fokalna segmentalna glomeruloskleroza; IFTA = intersticijska fibroza i tubularna atrofija; MEST T = zbroj intersticijske fibroze $i$ tubularne atrofije u Oksfordskoj klasifikaciji; IF = imunofluorescentna

(9). In our study, respiratory system infections and the administration of medications and vaccines equally preceded the occurrence of IgA vasculitis, and there was no occurrence of neoplasm in this patient study group. The data from the research conducted by Mitsui et al. speak in favour of a clear connection between neoplasms and the occurrence of IgA vasculitis, in contrast to the data found in the research conducted by Alojzija Hočevar et al. The median age of our patients was 57 , which is higher compared to the published data from the study conducted by Hung et al., in which the median age of patients was 44 (25), as well as the studies conducted by Kang et al., in which the median age of patients was 48 (9), and lower compared to the data from the study conducted by Alojzija Hočevar et al., in which the median age of the patients was 66 (23). In this study, we have observed a slightly more frequent incidence of the disease in males, which is in accordance with the data published so far. So, for example, in a study conducted by García et al., the ratio of males to females was 2.4: 1 , in a study conducted by JI Shin et al. it was 1.2: 1 , and in our study, it was 1.2: $1(26,27)$. All of our patients experienced skin changes and exhibited signs of kidney disease, and more than half of the patients experienced joint pain. Data from previ-
TABLE 5. Treatment of patients with IgA vasculitis

TABLICA 5. Liječenje oboljelih od IgA-vaskulitisa

\begin{tabular}{|l|c|}
\hline $\begin{array}{l}\text { Treatment with renin-angiotensin } \\
\text { system inhibitors prior to the diagnosis } \\
\text { (no/yes, < 1 year / yes, > 1 year) }\end{array}$ & All / Svi (n =22) \\
$\begin{array}{l}\text { / Terapija inhibitorima sustava } \\
\text { renin-angiotenzin prije dijagnoze } \\
\text { (ne / da, < 1 godina / da, > 1 godina) }\end{array}$ & \begin{tabular}{c} 
/ $4(18,2 \%)$ \\
\hline $\begin{array}{l}\text { Treatment with renin-angiotensin } \\
\text { system inhibitors after the diagnosis }\end{array}$
\end{tabular} \\
$\begin{array}{l}\text { / Terapija inhibitorima sustava } \\
\text { renin-angiotenzin poslije dijagnoze }\end{array}$ & $18(81,8 \%)$ \\
\hline $\begin{array}{l}\text { Glucocorticoids / Glukokortikoidi } \\
\text { Cyclophosphamide / Ciklofosfamid }\end{array}$ & $21(95,5 \%)$ \\
\hline $\begin{array}{l}\text { Mycophenolate mofetil } \\
\text { / Mikofenolat-mofetil }\end{array}$ & $5(22,7 \%)$ \\
\hline $\begin{array}{l}\text { Acute hemodialysis } \\
\text { / Akutna hemodijaliza }\end{array}$ & $1(4,5 \%)$ \\
\hline
\end{tabular}

RAAS = renin-angiotensin-aldosterone system / renin-angiotenzin-aldosteronski sustav

sloj dobi. Za razliku od IgA-vaskulitisa u djece, kad bolesti najčešće prethode infekcije respiratornog sustava, u odraslih se češće spominju primjena lijekova i 
ous studies suggest a higher incidence of joint pain in children than in adults (28). It is most commonly a case of oligoarthritis involving the knee, hip, and ankle (13). It is known that IgA vasculitis is generally a mild disease with a good prognosis, and the complications and deaths that can occur are associated with IgA nephritis and other rare complications of the disease. The results of numerous studies show that IgA nephritis in adults is more severe than in children and tends to lead to the development of nephrotic syndrome, arterial hypertension, increased serum creatinine and chronic renal failure (29-31). In a study conducted by Kang et al., renal disease, with the development of nephrotic syndrome and renal failure, was present in $80 \%$ of adults, while microhematuria and mild renal impairment occurred in $30 \%$ of children with IgA vasculitis (9). In our study, almost $50 \%$ of patients had asymptomatic hematuria, $49 \%$ had nephrotic syndrome, and $14 \%$ had subnephrotic proteinuria, while the smallest number of patients experienced the most severe clinical form - nephritic syndrome. Increased serum IgA values are more common in adults with IgA vasculitis. In the case of our patients, mean IgA values were normal, as were the values of the complement components (C3 and C4) and serum creatinine values. Further research should be conducted on more patients in order to make the results and conclusions more reliable. According to the published results of previous research, low $\mathrm{C} 3$ values are among the risk factors for the development of nephritis (16). In order to make a pathohistological diagnosis during this study, the Oxford classification was used, in accordance with which the morphological features of the biopsy were evaluated. In clinical practice, there is a lack of consensus on the use of a single classification for the evaluation of the active and chronic components of the disease, which would be validated for IgA nephritis (32). It is a known fact that the Haas classification and the Oxford classification have been validated only for IgA nephropathy, although we also use them for IgA vasculitis with nephritis, as well as the ISKDC classification (International Study of Kidney Disease in Children) which is most commonly used in children. IgA vasculitis is spontaneously resolved in $94 \%$ of children and in $89 \%$ of adults (33). In our study, all patients, except one, were treated with glucocorticoids. Previous research shows that patients with severe IgA nephritis require treatment with glucocorticoids and immunosuppressants in order to achieve remission more quickly (34, 35). Treatment of IgA nephritis patients with hematuria and proteinuria also includes the use of RAAS inhibitors, angiotensin-converting enzyme (ACE) inhibitors or angiotensin receptor blockers (ARBs) (36). In our study, this therapy was administered to $80 \%$ of patients. Cyclophosphamide was administered to five pa- neoplazme (9). U našem istraživanju infekcije respiratornog sustava i uzimanje lijekova i cjepiva podjednako su prethodili IgA-vaskulitisu, a neoplazma u ispitivanoj skupini bolesnika nije bilo. Podatci Mitsuija i suradnika govore u prilog jasnoj povezanosti neoplazma i pojave IgA-vaskulitisa, a za razliku od podataka Alojzije Hočevar i suradnika $(23,24)$. Medijan dobi naših bolesnika bio je 57 godina, što je više u usporedbi s objavljenim podatcima Hunga i suradnika, kod kojih je medijan dobi bolesnika bio 44 godine (25), kao $\mathrm{i}$ istraživanja Kanga i suradnika s medijanom dobi od 48 godina (9), a manje u usporedbi s podatcima Alojzije Hočevar i suradnika u kojih je medijan dobi bolesnika bio 66 godina (23). Uočili smo nešto češću pojavnost bolesti u muškaraca, što je u skladu s dosad objavljenim podatcima. Tako je, primjerice, $u$ istraživanju Garcíje i suradnika omjer muškaraca prema ženama bio $2,4: 1$, u istraživanju Jae Shin i suradnika iznosio je $1,2: 1$, a u našem je istraživanju taj omjer bio $1,2: 1$ (26, 27). Svi naši bolesnici imali su kožne promjene i znakove bubrežne bolesti, a bol u zglobovima imalo je više od polovine bolesnika. Podatci dosadašnjih istraživanja govore u prilog većoj pojavnosti boli u zglobovima u djece nego u odraslih (28). Najčešće je riječ o oligoartritisu sa zahvaćanjem koljena, kuka i gležnja (13). Poznato je da je IgA-vaskulitis uglavnom blaga bolest $s$ dobrom prognozom, a komplikacije i smrtne ishode do kojih može doći povezujemo s IgA-nefritisom i rijetkim drugim komplikacijama bolesti. Rezultati brojnih istraživanja pokazuju da je IgA-nefritis u odraslih teži nego u djece te ima tendenciju razvoja nefrotskog sindroma, arterijske hipertenzije, porasta serumskih vrijednosti kreatinina i kroničnoga bubrežnog zatajenja $(29$ - 31). U istraživanju Kanga i suradnika bubrežna bolest, uz razvoj nefrotskog sindroma i bubrežnog zatajenja, bila je prisutna u $80 \%$ odraslih, dok su u $30 \%$ djece s IgA-vaskulitisom bili izraženi mikrohematurija i blago bubrežno oštećenje (9). U našem istraživanju asimptomatsku hematuriju imalo je gotovo $50 \%$ bolesnika, nefrotski sindrom njih $49 \%$, a subnefrotsku proteinuriju $14 \%$ bolesnika, dok je najmanji dio bolesnika imao najteži klinički oblik - nefritički sindrom. Povišene serumske vrijednosti IgA češće se javljaju u odraslih s IgA-vaskulitisom. Srednje vrijednosti IgA u naših bolesnika bile su uredne, kao i vrijednosti komponenata komplementa (C3 i C4) i serumske vrijednosti kreatinina. Trebalo bi provesti daljnja istraživanja na većem broju bolesnika da bi rezultati i zaključci bili pouzdaniji. Prema objavljenim rezultatima dosadašnjih istraživanja, u rizične čimbenike za razvoj nefritisa ubrajaju se i niske vrijednosti C3 (16). Za patohistološku dijagnostiku tijekom ovog istraživanja rabili smo Oksfordsku klasifikaciju prema kojoj su se ocjenjivala morfološka obilježja bioptata. U kliničkoj praksi nedostaje konsenzus o uporabi jedinstvene klasifikacije s pomo- 
tients, mycophenolate mofetil was administered to one patient, and one patient was treated with hemodialysis. There are currently no randomised controlled trials that clearly define the treatment of children and adults with IgA nephritis. However, in addition to the administration of glucocorticoids, ACE inhibitors, and angiotensin receptor blockers, most studies include the administration of immunosuppressants (11). It is generally accepted that morbidity from IgA vasculitis depends on the degree of renal involvement (1). In this study, patient follow-up was performed for 23 to 84 months and, in the said period, all of them had improved or stagnant renal function, except for one patient treated with hemodialysis, who died due to numerous comorbidities and old age.

\section{CONCLUSION}

The results of our study confirmed that most patients with IgA vasculitis have a good prognosis. In adults, in whom IgA vasculitis occurs less frequently than in children, renal complications may develop, which are the leading cause of death and the most important factor for the final outcome of the disease. Kidney biopsy is an important invasive diagnostic method to confirm the diagnosis of nephritis. This study demonstrated the importance of knowing the clinical, laboratory, and pathohistological characteristics of adult patients with IgA vasculitis. In everyday work, it is important to determine characteristics of renal changes in IgA vasculitis in order for an adequate therapeutic option to be applied. ću koje bi se procjenjivale aktivna i kronična komponenta bolesti, a bila bi validirana za IgA-nefritis (32). Poznato je da su Haasova klasifikacija i Oksfordska klasifikacija validirane samo za IgA-nefropatiju, premda ih rabimo i za IgA-vaskulitis s nefritisom, kao i klasifikaciju ISKDC-a (engl. International Study of Kidney Disease in Children) koja se najčešće upotrebljava $\mathrm{u}$ djece. IgA-vaskulitis prolazi spontano u $94 \%$ djece i u $89 \%$ odraslih (33). U našem istraživanju svi su bolesnici, izuzevši jednoga, liječeni glukokortikoidima. Dosadašnja istraživanja pokazuju da bolesnici s teškim IgA-nefritisom iziskuju liječenje glukokortikoidima i imunosupresivima radi bržeg postizanja remisije (34, 35). Liječenje oboljelih od IgA-nefritisa s hematurijom i proteinurijom uključuje i primjenu inhibitora RAAS-a, inhibitora enzima koji konvertira angiotenzin (ACE-inhibitore) ili blokatora angiotenzinskih receptora (36). U našem istraživanju navedenu terapiju uzimalo je $80 \%$ bolesnika. Ciklofosfamid primalo je petero bolesnika, jedan je bolesnik primao mikofenolat-mofetil, a jedna je bolesnica liječena hemodijalizom. Zasad nema randomiziranih kontroliranih studija koje bi jasno definirale liječenje djece i odraslih oboljelih od IgA-nefritisa. Ipak, uz glukokortikoide, ACE-inhibitore i blokatore angiotenzinskih receptora, većina istraživanja uključuje i primjenu imunosupresiva (11). Općenito vrijedi da morbiditet od IgA-vaskulitisa ovisi o stupnju zahvaćenosti bubrega (1). U svojem istraživanju pratili smo bolesnike tijekom razdoblja od 23 do 84 mjeseca i svi su imali poboljšanu ili stagnirajuću bubrežnu funkciju, osim jedne bolesnice koja je liječena hemodijalizom te je zbog brojnih komorbiditeta i visoke dobi preminula.

\section{ZAKLJUČAK}

Rezultati našeg istraživanja potvrdili su da većina bolesnika s IgA-vaskulitisom ima dobru prognozu. U odraslih, u kojih se IgA-vaskulitis javlja rjeđe nego u djece, može doći do razvoja bubrežnih komplikacija koje su glavni uzrok smrtnih ishoda i najvažniji čimbenik za konačan ishod bolesti. Biopsija bubrega važna je invazivna dijagnostička metoda za potvrdu dijagnoze nefritisa. Ovo istraživanje pokazalo je važnost poznavanja kliničkih, laboratorijskih i patohistoloških karakteristika odraslih bolesnika s IgA-vaskulitisom. Pri svakodnevnom radu valja utvrditi značajke bubrežnih promjena da bismo na temelju tih obilježja primijenili prikladnu terapiju. 


\section{REFERENCES / LITERATURA}

1. Trnka P. Henoch-Schönlein purpura in children. J Paediatr Child Health. 2013;49:995-1003.

2. Piram M, Mahr A. Epidemiology of immunologlobulin A vasculitis (Henoch-Schönlein): cuurrent state of knowledge. Curr Opin Rheumatol. 2013;25:171-8.

3. Heineke $\mathrm{MH}$, Ballering AV, Jamin A i sur. New insights in the pathogenesis of immunoglobulin A vasculitis (Henoch-Schönlein purpura). Autoimmun Rev. 2017;16:1246-53.

4. Jelušić M, Malčić I i sur. Pedijatrijska reumatologija. Zagreb: Medicinska naklada; 2014.

5. Rigante D, Castellazzi L, Bosco A, Esposito S. Is there a crossroad between infections, genetics, and Henoch-Schönlein purpura? Autoimmun Rev. 2013;12:1016-21.

6. López-Mejías R, Genre F, Pérez BS i sur. Association of HLA$B \star 41: 02$ with Henoch-Schönlein Purpura (IgA vasculitis) in Spanish individuals irrespective of the HLA-DRB1 status. Arthritis Res Ther. 2015;17:102.

7. Pellegrin MC, Matarazzo L, Neri E, Pennesi M, Crovella S. HLA-B35, a common genetic trait, in a familial case of Henoch-Schoenlein purpura and Berger's disease. Genet Mol Res. 2014;13:2669-73.

8. Saulsbury FT. Epidemiology of Henoch-Schönlein purpura. Cleve Clin J Med. 2002;69(Suppl. 2):SII87-9.

9. Kang Y, Park JS, Ha YJ i sur. Differences in clinical manifestations and outcomes between adults and child patients with $\mathrm{He}-$ noch-Schönlein purpura. J Korean Med Sci. 2014;29:198-203.

10. Ozen S, Pistorio A, Iusan SM, Bakkaloglu A, Herlin T, Brik R i sur. EULAR/PRINTO/PRES criteria for Henoch-Schönlein purpura, childhood polyarteritis nodosa, childhood Wegener granulomatosis and childhood Takayasu arteritis: Ankara 2008. Part II: Final classification criteria. Ann Rheum Dis. 2010;69(5):798-806.

11. González LM, Janniger CK, Schwartz RA. Pediatric Henoch-Schönlein purpura. Int J Dermatol. 2009;48:1157-65.

12. Hadman JM, Barqawi MA. Henoch-Schönlein purpura in children. Saudi Med J. 2008;29:549-52.

13. Wang X, Zhu Y, Gao L, Wei S i sur. Henoch-Schönlein purpura with joint involvement: Analysis of 71 cases. Pediatr Rheumatol Online J. 2016;14:20.

14. Da Dalt L, Zerbinati C, Strafella MS i sur. Henoch-Schönlein purpura and drug and vaccine use in childhood: a case-control study. Ital J Pediatr. 2016;42:60.

15. Dalpiaz A, Schwamb R, Miao Y, Gonka J i sur. Urological Manifestations of Henoch- Schönlein Purpura: A Review. Curr Urol. 2014;8:66-73.

16. Chan H, Tang Y-L, Lv X-H i sur. Risk Factors Associated with Renal Involvement in Childhood Henoch-Schönlein Purpura. A Meta-Analysis. Plos One. 2016;11:e0167346.

17. Haas M. IgA nephropathy and Henoch-Schönlein purpura. U: Jennette JC, Olson JL, Schwartz MM, Silva FG (ur.). Pathology of the Kidney. Philadelphia: Lippincott Williams \& Wilkins; 2007, str. 423-86.

18. Haas M. Histologic subclassification of IgA nephropathy: A clinicopathologic study of 244 cases. Am J Kidney Dis. 1997; 29:829-42.

19. Cattran DC, Coppo R, Cook HT i sur.; Working Group of the International IgA Nephropathy Network and the Renal Pathology Society. The Oxford classification of IgA nephropathy: ra- tionale, clinicopathological correlations, and classification. Kidney Int. 2009;76:534-45.

20. Trimarchi H, Barratt J, Cattran DC i sur.; IgAN Classification Working Group of the International IgA Nephropathy Network and the Renal Pathology Society. Oxford Classification of IgA nephropathy 2016: an update from the IgA Nephropathy Classification Working Group. Kidney Int. 2017;91:1014-21.

21. Stefek B, Beck M, Ioffreda M, Gardner L i sur. Henoch-Schönlein Purpura with Posterior Reversible Encephalopathy Syndrome. J Pediatr. 2015;167:1152-4.

22. Rajagopala S, Parameswaran S, Ajmera JS, Ganesh RN, Katrevul A. Diffuse alveolar hemorrhage in IgA nephropathy: case series and systemic review of the literature. Int J Rheum Dis. 2017;20:109-21.

23. Hočevar A, Rotar Z, Ostrovršnik J i sur. Incidence of IgA vasculitis in the adult Slovenian population. Br J Dermatol. 2014; 171:524-7.

24. Mitsui H, Shibagaki N, Kawamura T i sur. A clinical study of Henoch-Schönlein Purpura associated with malignancy. J Eur Acad Dermatol Venereol. 2009;23:394-401.

25. Hung S-P, Yang Y-H, Lin Y-T i sur. Clinical manifestations and outcomes of Henoch-Schönlein purpura: comparison between adults and children. Pediatr Neonatol. 2009;50:162-8.

26. García-Porrúa C, Calviño MC, Llorca J, Couselo JM, GonzálezGay MA. Henoch-Schönlein purpura in children and adults: clinical differences in a defined population. Semin Arthritis Rheum. 2002;32:149-56.

27. Shin JI, Park JM, Shin YH, Hwang DH, Kim JH, Lee JS. Predictive factors for nephritis, relapse, and significant proteinuria in childhood Henoch-Schönlein purpura. Scand J Rheumatol. 2006;35:56-60.

28. Jennette JC, Falk RJ, Andrassy K i sur. Nomenclature of systemic vasculitides. Proposal of an international consensus conference. Arthritis Rheum. 1994;37:187-92.

29. Uppal SS, Hussain MAS, Al-Raqum HA i sur. Henoch-Schönlein purpura in adults versus children/adolescents: A comparative study. Clin Exp Rheumatol. 2006;24:(2 Suppl 41):S26-30.

30. Pillebout E, Thervet E, Hill G i sur. Henoch-Schönlein Purpura in adults: outcomes and prognostic factors. J Am Soc Nephrol. 2002;13:1271-8.

31. Audemard-Verger A, Terrier B, Dechartres A i sur.; French Vasculitis Study Group. Characteristics and Management of IgA Vasculitis (Henoch-Schönlein) in Adults: Data From 260 Patients Included in a French Multicenter Retrospective Survey. Arthritis Rheumatol. 2017:69:1862-70.

32. Jelusic M, Sestan M, Cimaz R, Ozen S. Different histological classifications for Henoch-Schönlein purpura nephritis: which one should be used? Pediatr Rheumatol Online J. 2019;17:10.

33. Roberts PF, Waller TA, Brinker TM, Riffe IZ, Sayre JW, Bratton RL. Henoch-Schönlein Purpura: A review Article. South Med J. 2007;100:821-4.

34. Eleftheriou D, Brogan PA. Therapeutic advances in the treatment of vasculitis. Pediatr Rheumatol Online J. 2016;14:26.

35. González-Gay MA, Llorca J. Controversies on the use of corticosteroid therapy in children with Henoch-Schönlein purpura. Semin Arthritis Rheum. 2005;35:135-7.

36. Pohl M. Henoch-Schönlein purpura nephritis. Pediatr Nephrol. 2014;30:245-52. 